R. F. Samigullina, M. V. Rotermel ${ }^{*}$, I. V. Ivanova,

T. I. Krasnenko

Institute of Solid State Chemistry,

Ural Branch of the Russian Academy of Sciences,

91 Pervomaiskaya St., Ekaterinburg 620990, Russian Federation

${ }^{*}$ E-mail: rotermel@ihim.uran.ru

\title{
Sol-gel synthesis and crystal chemical properties of the pigment $\mathrm{Zn}_{1.9} \mathrm{Cu}_{0.1} \mathrm{SiO}_{4}$
}

The pigment $\mathrm{Zn}_{1.9} \mathrm{Cu}_{0.1} \mathrm{SiO}_{4}$ was obtained by the method of sol-gel synthesis. The crystallization temperature was set at $776{ }^{\circ} \mathrm{C}, \Delta H \approx-16.3 \mathrm{~kJ} / \mathrm{mol}$. Thermal expansion of the individual $\mathrm{Zn}_{2} \mathrm{SiO}_{4}$ and $\mathrm{Zn}_{1.9} \mathrm{Cu}_{0.1} \mathrm{SiO}_{4}$ solid solutions was studied by in situ high-temperature $\mathrm{X}$-ray diffraction. It is shown that the substitution of $\mathrm{Zn}^{2+} \rightarrow \mathrm{Cu}^{2+}$ does not lead to significant changes in the lattice parameters; in the range from room temperature to $800^{\circ} \mathrm{C}$ the structure expands monotonically when heated. The coefficients of volumetric thermal expansion for $\mathrm{Zn}_{2} \mathrm{SiO}_{4}$ and $\mathrm{Zn}_{1.9} \mathrm{Cu}_{0.1} \mathrm{SiO}_{4}$ are $\mathrm{a}_{\mathrm{v}}=8.05 \cdot 10^{-6}$ and $8.81 \cdot 10^{-6} 1 / \mathrm{K}$, respectively. The colorimetric coordinates in the RGB system are $71.8 \%$ red, $72.9 \%$ green and $79.6 \%$ blue, which corresponds to the gray-blue pigment.

Keywords: pigment; willemite; sol-gel synthesis; thermal expansion.

Received: 06.12.2018. Accepted: 21.12.2018. Published: 31.12.2018.

(c) Samigullina R. F., Rotermel M. V., Ivanova I. V., Krasnenko T. I., 2018

\section{Introduction}

Divalent metal silicates are widely used as luminescent, corrosion protecting, electrical insulating materials, catalysts, pigments. Thus, the emergence of the chemical manufacturing of synthetic pigments began with the production of dyed double silicates, known as egyptian blue $\mathrm{CaCuSi}_{4} \mathrm{O}_{10}$, han blue $\mathrm{BaCuSi}_{4} \mathrm{O}_{10}[1-3]$. The continued interest to the silicate pigments is caused due to the pure intense color, as well as by their high thermal and chemical resistance. Therefore, it is possible to use them for dyeing ceramic products that exposed to high temperature calcination in the manufacturing process.
Transition metal orthosilicates containing copper, nickel, and cobalt ions are well known as blue pigments. Dopant $\mathrm{M}^{2+}$ ions $(\mathrm{M}=\mathrm{Cu}, \mathrm{Ni}, \mathrm{Co})$ in $\mathrm{Zn}_{2-2 \mathrm{x}} \mathrm{M}_{2 \mathrm{x}} \mathrm{SiO}_{4}$ solid solutions are coordinated by four oxygen atoms, which causes the blue color of the compounds due to the splitting of electron levels of $\mathrm{M}^{2+}$ ions in the crystal field. Since the information about $\mathrm{Zn}_{2-2 x} \mathrm{M}_{2 \mathrm{x}} \mathrm{SiO}_{4}$ $(\mathrm{M}=\mathrm{Cu}, \mathrm{Ni}, \mathrm{Co})$ is limited, the purpose of this work is a disclosure of sol-gel synthesis mechanism for $\mathrm{Zn}_{1.9} \mathrm{Cu}_{0.1} \mathrm{SiO}_{4}$ and determination of main pigment characteristics, such as colorimetric parameters and thermal expansion coefficient. 


\section{Experimental}

The precursors used in the sol-gel synthesis of $\mathrm{Zn}_{1.9} \mathrm{Cu}_{0.1} \mathrm{SiO}_{4}$ were zinc acetate $\mathrm{Zn}\left(\mathrm{CH}_{3} \mathrm{COO}\right)_{2} \cdot 2 \mathrm{H}_{2} \mathrm{O}$, copper acetate $\mathrm{Cu}\left(\mathrm{CH}_{3} \mathrm{COO}\right)_{2} \cdot \mathrm{H}_{2} \mathrm{O}$, and tetraethyl orthosilicate (TEOS) $\mathrm{Si}\left(\mathrm{OC}_{2} \mathrm{H}_{5}\right)_{4}$. The phase composition within the range from room temperature up to $800^{\circ} \mathrm{C}$ was controlled in situ by the X-ray powder diffraction (XRPD) method (Shimadzu diffractometer, $\mathrm{CuKa}_{1}$ radiation, $2 \theta$ angle interval from 10 to $60^{\circ}$ with a step of $0.02^{\circ}$ ), comparing the XRD data with the X-ray characteristics of the possible impurity oxides and zinc silicates (PDF2 database, ICDD, USA, Release 2009). The temperature was controlled using an Anton Paar TTK-450 attachment. The unit cell parameters were refined by the Rietveld method using the Fullprof 2010 software. Thermogravimetric (TG) analysis together with differential thermal analysis (DTA) were performed using a Setsys Evolution thermal analyzer (Setaram) in air at a temperature scan rate of $10 \% \mathrm{~min}$ in the temperature range $20-1100^{\circ} \mathrm{C}$, with alumina as a reference substance. Colorimetric analysis was performed using an SLR Olympus e-420 (light source temperature of $5400 \mathrm{~K}$; ISO $=200$; light camera parameters $\mathrm{L} \times \mathrm{W} \times \mathrm{H}=$ $35 \times 25 \times 32 \mathrm{~cm}$ ) Photo Impact 12 program, through a calibrator monitor One-Eye Pro. The colorimetry results are given in the RGB color coordinates system.

\section{Results and discussion}

The synthesis method used in our work allowed us to obtain the $\mathrm{Cu}^{2+}$ dopant concentration equal to 5 at.\%. Hydrolysis of $\left[\mathrm{Si}\left(\mathrm{C}_{2} \mathrm{H}_{5} \mathrm{O}\right)_{4}\right]$ in the mixture with the ratio $\mathrm{H}_{2} \mathrm{O}$ :TEOS $=1: 1$ took place within $30 \mathrm{~min}$. The alcohol solutions of metal acetates and hydrolized TEOS were mixed. After the solutions were poured together the mixture was stirred on a magnetic stirrer for $1 \mathrm{~h}$. The precursor for the final stage of synthesis was obtained by evaporation of the mixture for 2 hours at $65^{\circ} \mathrm{C}$. The gel was formed after 2 days at room temperature.

In order to determine the temperature range of $\mathrm{Zn}_{1.9} \mathrm{Cu}_{0.1} \mathrm{SiO}_{4}$ formation, thermogravimetric and differential thermal analyses of the obtained precursor were carried out (Fig. 1).

The mass loss of 2-3\%, accompanied by a small endothermic effect at $100{ }^{\circ} \mathrm{C}$, corresponds to the removal of water and ethanol residual. The weight loss of about $20 \%$ with a simultaneous exothermic sig-

nal on the DTA curve within the region of $250-410^{\circ} \mathrm{C}$ is caused by the decomposition of organic components. The DTA curve shows the sharp exothermic effect $(\Delta H \approx-16.3 \mathrm{~kJ} / \mathrm{mol}$ ) with a maximum at $776^{\circ} \mathrm{C}$, while the mass of the sample remains constant. The assignment of this effect was determined by the thermal analysis of $\mathrm{Zn}_{2} \mathrm{SiO}_{4}$ precursor, prepared from zinc acetate and TEOS (Fig. 2). The exothermic effect recorded on the DTA curve in the temperature range $320-500^{\circ} \mathrm{C}$ with simultaneous mass loss on the TG curve corresponded to the decomposition of organic components. The exothermic effect at $786^{\circ} \mathrm{C}(\Delta \mathrm{H} \approx-15.5 \mathrm{~kJ} / \mathrm{mol})$ with a constant sample mass is similar to that observed on the DTA curve for the precursor with the nominal composition $\mathrm{Zn}_{1.9} \mathrm{Cu}_{0.1} \mathrm{SiO}_{4}$ (Fig. 1). Consequently, one can conclude that the exothermal effects on the compared DTA curves for the $\mathrm{Zn}_{2} \mathrm{SiO}_{4}$ and $\mathrm{Zn}_{1.9} \mathrm{Cu}_{0.1} \mathrm{SiO}_{4}$ precursors are of the same nature, and both are related 
to the process of a phase with the willemite structure formation. Thus, a comparative analysis of the thermal behavior of these samples showed that at temperatures above $776^{\circ} \mathrm{C}$ the process of forming a long-range order at sol-gel synthesis of $\mathrm{Zn}_{1.9} \mathrm{Cu}_{0.1} \mathrm{SiO}_{4}$ was completed.

XRD data of the $\mathrm{Zn}_{1.9} \mathrm{Cu}_{0.1} \mathrm{SiO}_{4}$ precursor annealed at $800{ }^{\circ} \mathrm{C}$ does indicate the formation of the phase with the willemite structure; however, an insignificant admixture of copper (II) oxide is present in the sample (Fig. 3). The single-phase product was obtained by firing the precursor sample at $900^{\circ} \mathrm{C}$ (Fig. 3).

$\mathrm{X}$-ray pattern of the single phase $\mathrm{Zn}_{1.9} \mathrm{Cu}_{0.1} \mathrm{SiO}_{4}$ sample taken at room temperature was indexed in the willemite type structure with the trigonal space group $R \overline{3}$. The refined unit cell parameters, unit cell volume and number of formula units are: $a=13.927(1) \AA, c=9.305(3) \AA, V=$ 1563.03(8) $\AA^{3}, Z=18$.

One of the most important characteristics of the pigment is the volumetric thermal expansion coefficient (VTEC), which should be comparable to the thermal expansion of the coated material. Colored zinc orthosilicate doped with copper may

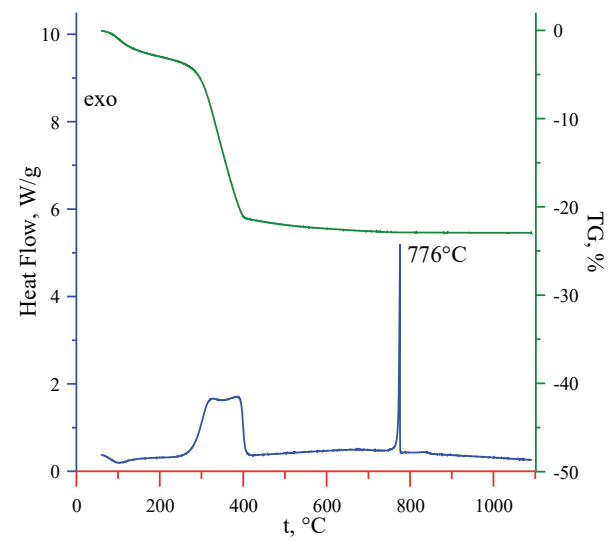

Fig. 1. TG and DTA curves (on heating) of the $\mathrm{Z}_{1.9} \mathrm{Cu}_{0.1} \mathrm{SiO}_{4}$ precursor be suitable as a pigment for ceramics made of porcelain, earthenware, majolica. Manufacturing and operation proceeds in wide temperature range, therefore, the coincidence VTEC of the matrix and the pigment will allow to avoid cracking of the coating.



Fig. 2. Heating TG and DTA curves of the $\mathrm{Zn}_{2} \mathrm{SiO}_{4}$ precursor

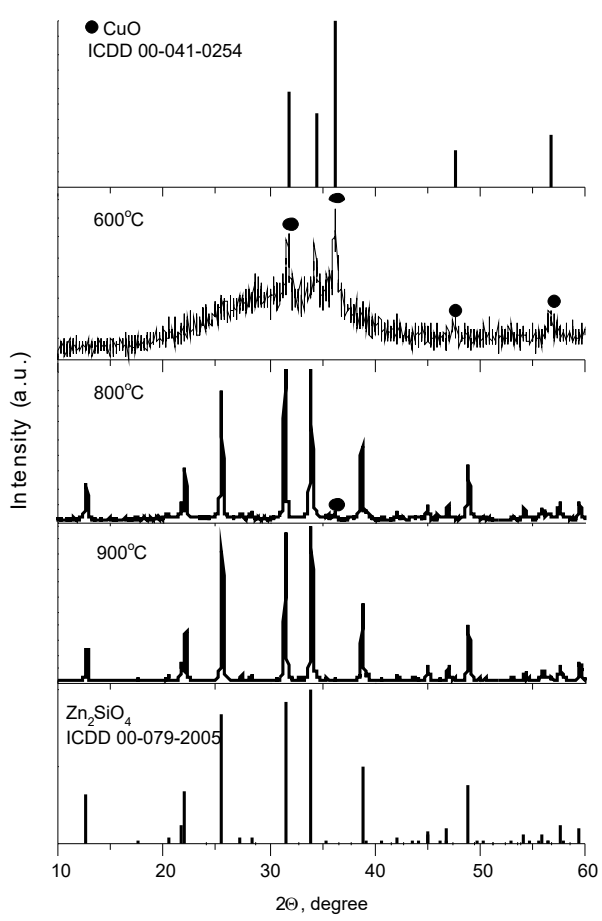

Fig. 3. X-ray diffraction profiles of $\mathrm{Zn}_{1.9} \mathrm{Cu}_{0.1} \mathrm{SiO}_{4}$ powder annealed at different temperatures 


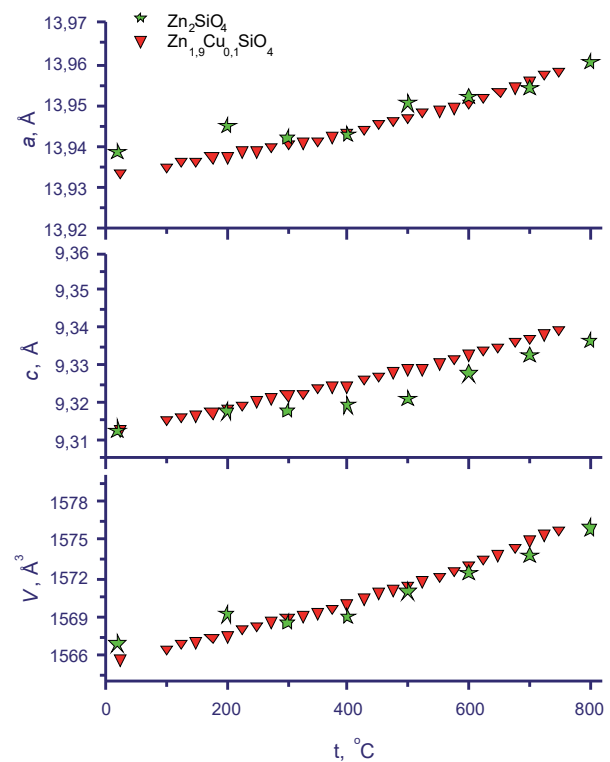

Fig. 4. The unit cell parameters and unit cell volume for $\mathrm{Zn}_{2-2 x} \mathrm{Cu}_{2 \mathrm{x}} \mathrm{SiO}_{4}(x=0,0.05)$ versus temperature

The values of VTEC were calculated from the experimental results for the $\mathrm{Zn}_{2-2 x} \mathrm{Cu}_{2 x} \mathrm{SiO}_{4}$ unit cell parameters $(x=0$; 0.05 ) in the range from room temperature up to $800{ }^{\circ} \mathrm{C}$ (Fig. 4). It was shown that the sizes of the unit cell for the zinc orthosilicate $\mathrm{Zn}_{2} \mathrm{SiO}_{4}$ and $\mathrm{Zn}_{1.9} \mathrm{Cu}_{0.1} \mathrm{SiO}_{4}$ solid solution monotonically expanded with
Table 1

Volume thermal expansion coefficients for the often used ceramics and $\mathrm{Zn}_{2-2 x} \mathrm{Cu}_{2 \mathrm{x}} \mathrm{SiO}_{4}$

\begin{tabular}{c|c}
\hline Material & $\alpha_{V} \cdot 10^{-6}, 1 / \mathrm{K}$ \\
\hline $\mathrm{Zn}_{2} \mathrm{SiO}_{4}$ & 8.05 \\
\hline $\mathrm{Zn}_{1.9} \mathrm{Cu}_{0.1} \mathrm{SiO}_{4}$ & 8.81 \\
\hline Porcelain & $5.5-7.0$ \\
\hline Earthenware & $7.0-8.1$ \\
\hline Majolica & $8.5-10.0$
\end{tabular}

increasing temperature. Doping of zinc orthosilicate with the cations with similar size, like $\mathrm{Cu}^{2+}$ (for c.n. $=4 r_{\mathrm{Zn}^{2+}}=0.74 \AA$, $r_{\mathrm{Cu}^{2+}}=0.71 \AA$ ) does not lead to significant differences in the polyterms of unit cell parameters. A comparison of VTEC for $\mathrm{Zn}_{2-2 x} \mathrm{Cu}_{2 x} \mathrm{SiO}_{4}(x=0 ; 0.05)$ with that for the ceramic substrate [4], most often used as a coated material (Table 1), shows their proximity.

Colorimetric coordinates of blue-gray $\mathrm{Zn}_{1.9} \mathrm{Cu}_{0.1} \mathrm{SiO}_{4}$ in the RGB color space consists of $71.8 \%$ red, $72.9 \%$ green and $79.6 \%$ blue (the percentages are relative to pure color), the color saturation is $16.1 \%$.

\section{Conclusion}

The gray-blue pigment $\mathrm{Zn}_{1.9} \mathrm{Cu}_{0.1} \mathrm{SiO}_{4}$ was obtained by the sol-gel synthesis method. The consequence of phase transformations during the synthesis of the $\mathrm{Zn}_{1.9} \mathrm{Cu}_{0.1} \mathrm{SiO}_{4}$ solid solution was disclosed with the help of X-ray diffraction and thermal analysis. In situ high-temperature

$\mathrm{X}$-ray study for $\mathrm{Zn}_{2-2 \mathrm{x}} \mathrm{Cu}_{2 \mathrm{x}} \mathrm{SiO}_{4}(x=0 ; 0.05)$ in the range of $25-800{ }^{\circ} \mathrm{C}$ showed that the volume thermal expansion of the ceramic pigment reveals monotonic character. The calculated VTEC value for $\mathrm{Zn}_{2-2 x} \mathrm{Cu}_{2 x} \mathrm{SiO}_{4}$ is close to VTEC reported for porcelain, earthenware, majolica.

\section{Acknowledgements}

The work was supported by UB RAS (project 18-10-3-32).

\section{References}

1. Berke H. The invention of blue and purple pigments in ancient times. Chem. Soc. Rev. 2007;36:15-30. DOI: 10.1039/B606268G. 
2. Pozza G., Ajo` D., Chiari G., De Zuane F., Favaro M. Photoluminescence of the inorganic pigments Egyptian blue, Han blue and Han purple. J. Cultural Heritage. 2000;1:393-8. DOI: 10.1016/S1296-2074(00)01095-5.

3. Sidorov V.I., Malayvskyi N.I., Pokid 'ko B. V. Poluchenie nizkoosnovnikh silikatov nekotorikh perekhodnikh metallov metodom osadzenizya. Vestnik MGSU. 2007;1:163-6. Russian.

4. Khleborodova O. A. Tablica sootvetstviya keramicheskikh mass I bazovikh glazurei [Internet]. 2017. Russian. Available from: https://www.ceramistam.ru/blog/Keramicheskie_massy/tablitsa-sootvetstviya-keramicheskikh-mass-i-bazovykh-glazurey/. 